burrowed into the dirt floor of the house in search of a pupation site are not controlled by these insecticide ap plications.

Litter management. When boron products are applied, the practice of scraping out the litter after each brood apparently allows many adult mealworms to emerge unharmed from the soil, because the boron compounds they would otherwise have contacted have gone out with the litter. The result is a rapid population increase during subsequent broods.

Reinfestation. Complete elimination of the lesser mealworm from infested premises is difficult with some current husbandry practices.

Reinfestation has been observed to occur in several ways. The practice of scraping used litter from brooder houses into a pile just outside the end door encourages reinfestation. Frequently, after a house is cleaned and disinfected, new litter is delivered to the opposite end of the house and scraped into the house before the pile of used litter is removed. Adult lesser mealworms have been observed moving at night from the used litter pile to other locations, including the cleaned and disinfected house.

Mealworm larvae may leave the house and burrow into the soil outside the house to pupate. The emerging adults may return to the house. $\mathrm{Mi}$ grating larval stages have been found in the walls and the insulation, and pupating has been observed in the dust between the walls and in the insulation.

Probably the most insidious source of reinfestation is pupation in the floor of the house, untouched by the removal of the used litter and disinfection of the house before the next brood arrives. By the time the new brood is in place, newly emerged adult mealworms will be in the clean house and potentially carrying disease organisms from the previous brood.

John C. Voris is Area Turkey Specialist, Ralph Pfost was Poultry Farm Advisor and Romney Woodbury was Staff Research Associate, all at UC Davis (located at Kearney Agricultural Center); Jeffery A. Meyer was Entomologist, UC Riverside.

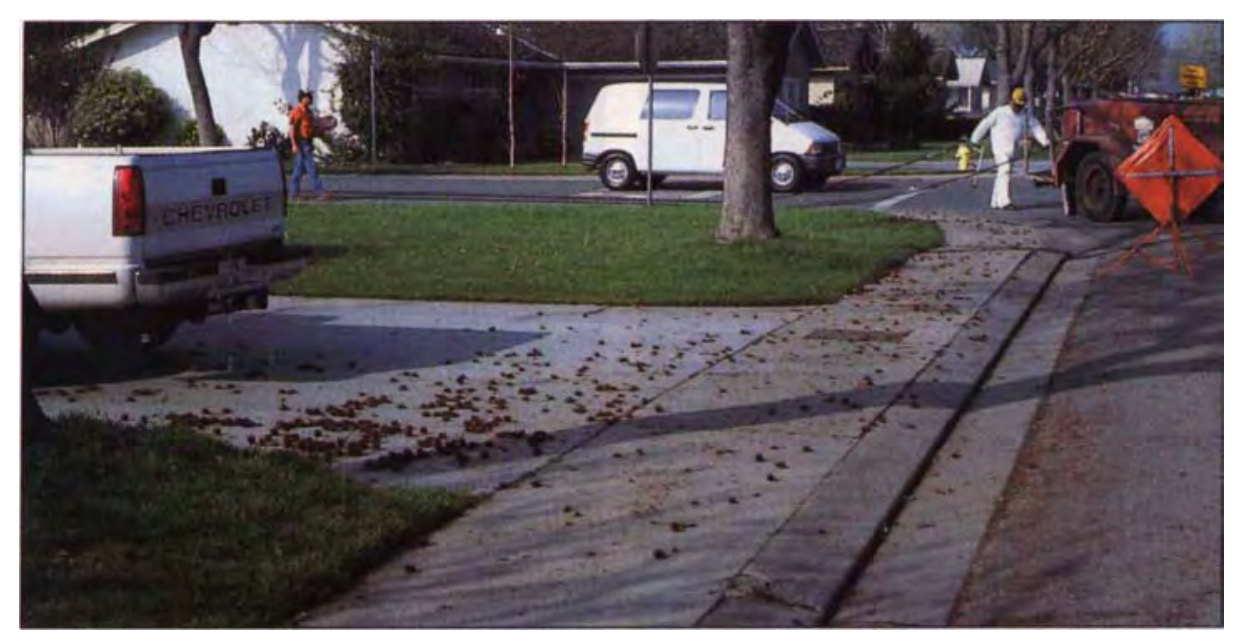

Liquidambar fruit hang on the trees through winter, then drop in early spring in great numbers.

\title{
Ethephon sprays eliminate the messy, hazardous fruits of flowering pear and liquidambar
}

\author{
Ed Perry $\quad$ Allen Lagarbo
}

\section{Two commonly planted street trees - flowering pear and liq- uidambar - produce heavy crops of fruits that are not only un- sightly, but also create slippery sidewalks. Trials have now shown that almost all of the fruits of both species can be eliminated by ethephon sprays applied at full bloom.}

Ornamental flowering pear (Pyrus calleryana) and American sweetgum or liquidambar (Liquidambar styraciflua) are common landscape trees in California. They are planted for their beauty and other desirable features, but their fruits are hazardous, especially on streets, sidewalks and driveways. The 'Aristocrat' cultivar of flowering pear is especially fruitful.
In cities where these species are planted as street trees, parks departments have to deal with numerous complaints from pedestrians about the unsightly mass of crushed slippery fruits that fall from the trees. And if the trees are growing in city easements, the city is liable for any injuries the nuisance fruits cause.

Both liquidambar and flowering pear produce fruits that hang in the trees throughout the winter and fall in great number in early spring. Liquidambar produce golf ball-sized spiny fruits. The fruits of the flowering pear are small, round and inedible. They attract flocks of cedar waxwings, robins and other birds, which leave copious droppings, a major cause of citizen complaints. Flowering pear trees also often become heavily infested 


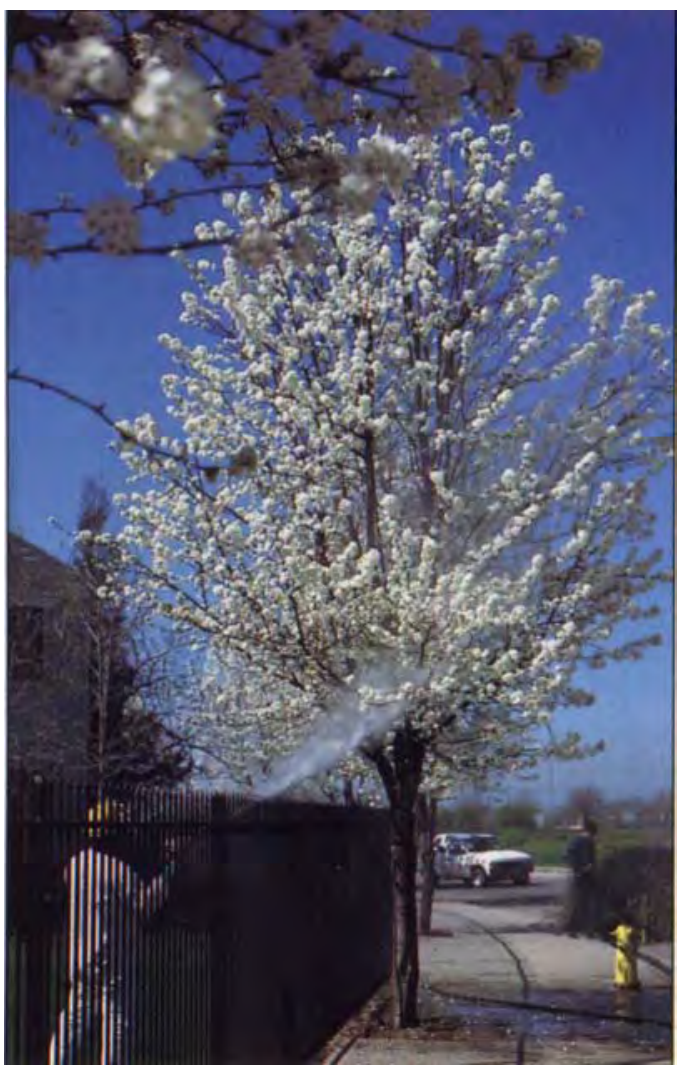

Ethephon spray being applied to 'Aristocrat' flowering pear at full bloom, the optimum application time (March 1989).

with broad-leaved mistletoe, as the pear fruits attract birds carrying mistletoe seed from other locations. Controlling the mistletoe is another parks department expense.

In California, the plant growthregulating chemical ethephon (Monterey Florel Brand Fruit Eliminator, Rhone-Poulenc Ag Co.) is currently registered for eliminating the nuisance fruits of apple, crab apple, carob and olive. When applied to plants, ethephon releases ethylene, a gas that causes abscission layers (layers of cells) to form between the small fruits and stems; this causes the fruit to drop before it can successfully set. In response to requests from landscape maintenance gardeners and city parks departments, we studied the efficacy of ethephon in preventing flowering pear and liquidambar trees from producing the nuisance fruits, looking for the optimum ethephon concentration and any phytotoxic reactions.

\section{Street tree trials}

We conducted trials in 1989, 1991 and 1992 on heavy-fruit-producing mature trees (over 10 years old) being

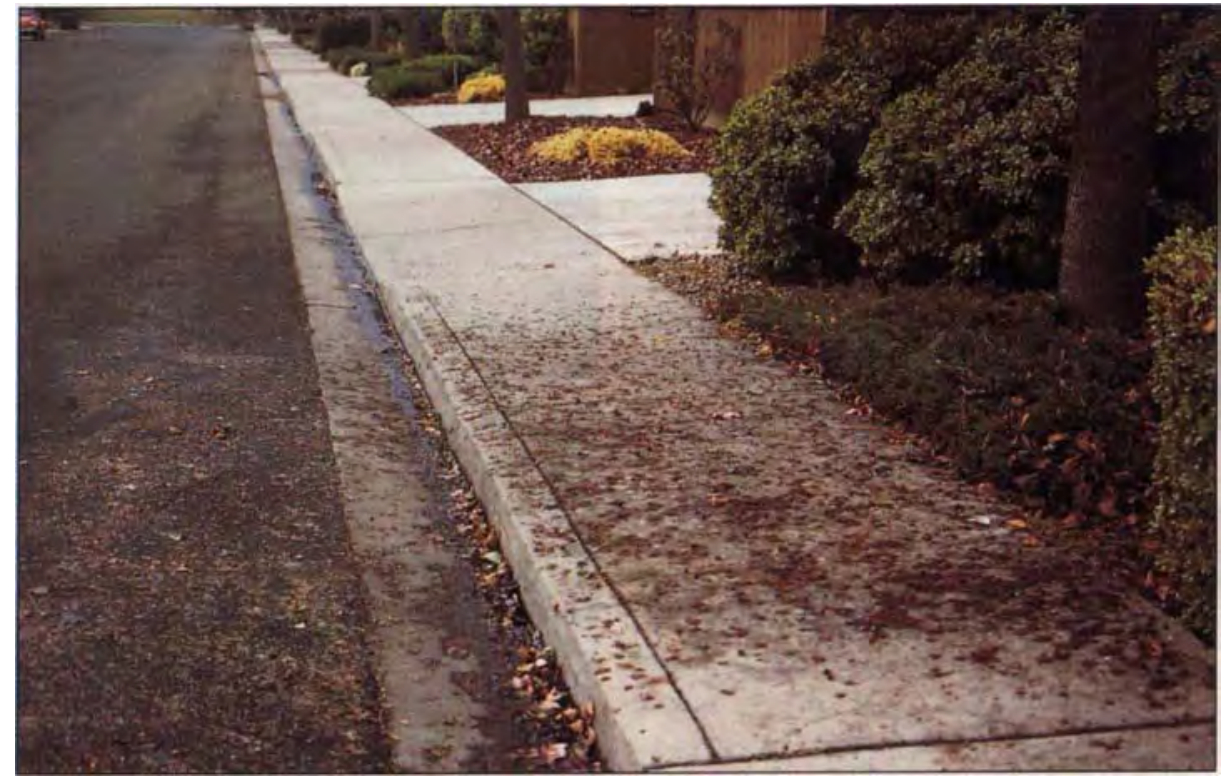

An 'Aristocrat' flowering pear has littered the sidewalk and street with its crushed fruit, rendering the area slippery and unsightly (January 1991).

maintained as street trees by the City of Modesto Parks Department in Modesto, California.

In the flowering pear trial, our treatments consisted of ethephon at 1,000 and $2,000 \mathrm{ppm}$, and an untreated control. The 1,000 ppm treatment represents the standard label rate for eliminating fruit in olive and the high label rate for eliminating fruit in apple and crab apple. Spray treatments were made on March 15, 1989, during full bloom; temperatures at the time of treatment were $55^{\circ}$ to $60^{\circ} \mathrm{F}$. Trees were sprayed to runoff, using approximately 10 gallons of mixed material per tree. A 500-gallon Bean sprayer was used to apply the sprays. This trial consisted of seven single tree replications per treatment.

We conducted two trials on liquidambar. In Trial 1, treatments consisted of ethephon at 1,000 and 2,000 ppm, and an untreated control. Spray treatments were made on April 1, 1991, at full bloom; newly emerging leaves ( $1 / 4$ to $1 / 2$ inch long) were present at the time of treatment; temperatures at the time of treatment were $58^{\circ}$ to $60^{\circ} \mathrm{F}$. As in the flowering pear trial, trees were sprayed to runoff, using approximately 10 gallons of mixed mate- rial per tree. Trial 1 consisted of 10 single tree replications per treatment.

In Trial 2, treatments consisted of ethephon at 500 and $750 \mathrm{ppm}$, and an untreated control. Sprays were applied on March 18, 1992, at full bloom; newly emerging leaves $(1 / 4$ to $1 / 2$ inch long) were present; temperatures were $60^{\circ}$ to $65^{\circ} \mathrm{F}$. Trial 2 consisted of seven single tree replications per treatment.

We evaluated the effectiveness of the flowering pear treatments on May 10,1989 , when the fruits matured. Because foliage hid the green-brown fruits of the liquidambar, we had to wait until nearly complete leaf drop to properly evaluate the liquidambar trials: Trial 1 treatments were evaluated on December 6, 1991; Trial 2 treatments on December 15, 1992. We counted the number of fruits on five secondary lateral branches, selected randomly, in each of the trees in the test plots. Then we calculated the average number of fruits for each treatment. From counts made at the same time on untreated trees, we determined that liquidambars at this site had an average of 46 fruits per secondary lateral branch, and flowering pears had an average of 296 fruit per secondary lateral branch. Dividing the test 


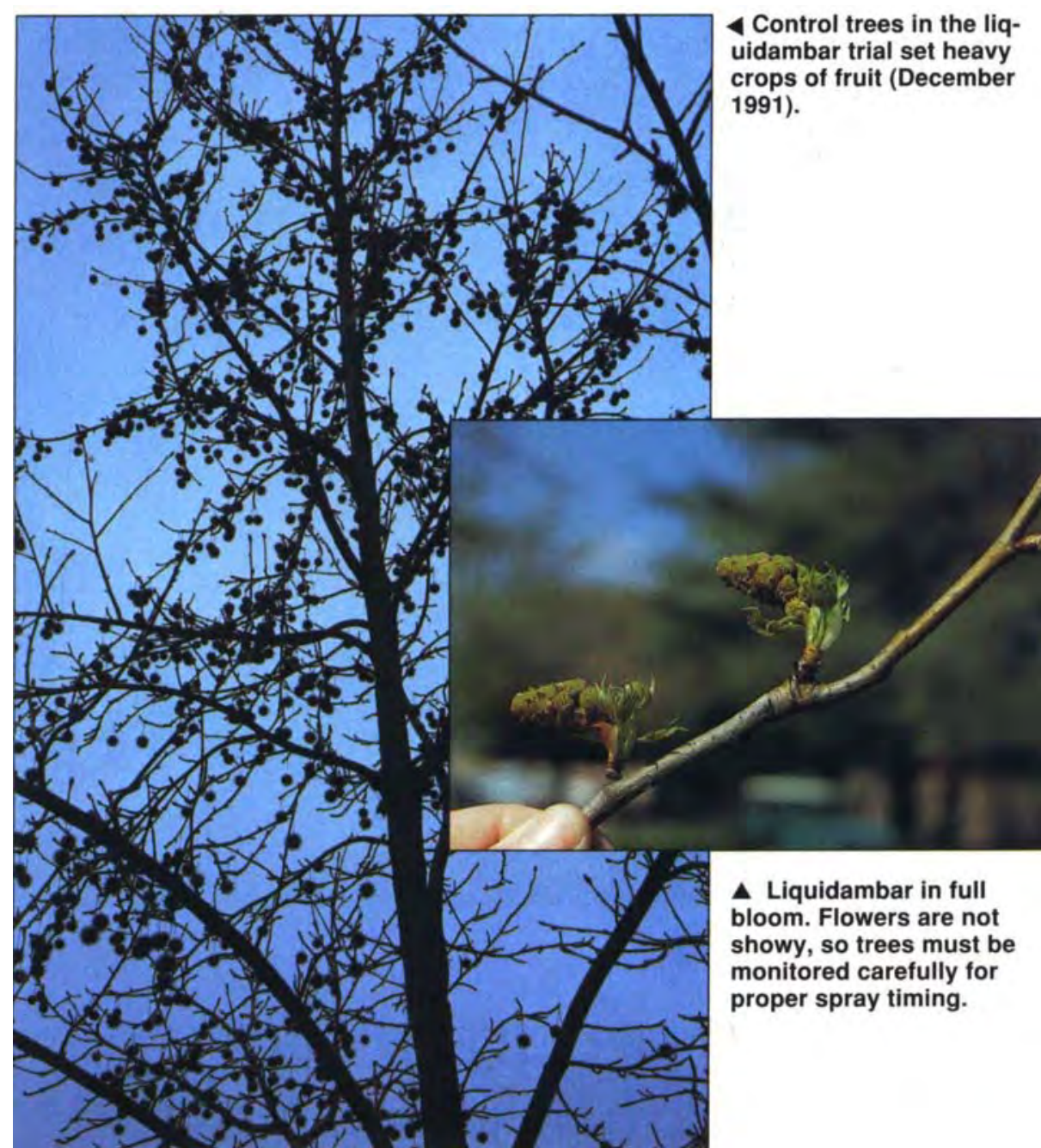

plot averages by these baseline figures gave us the percentage of fruit remaining in test trees; subtracting the percentage of fruit remaining in test trees from 100 gave us the percentage of fruit eliminated.

\section{Optimum spray rates}

Ethephon at both 1,000 and 2,000 ppm was effective in eliminating the fruits of flowering pear (table 1) and liquidambar (table 2, Trial 1); at least $95 \%$ of the fruits were eliminated in both species, leaving insignificant amounts of fruit in the treated trees. The lower rates of ethephon, $500 \mathrm{ppm}$ and $750 \mathrm{ppm}$, sprayed on the Trial 2 liquidambars reduced fruit set significantly compared with the untreated control trees (table 2, Trial 2), but still eliminated only $32.9 \%$ and $31.4 \%$ of the fruit, leaving unacceptable amounts of fruit in the trees.
We observed the test trees closely three or four times before evaluating the fruit elimination, and again the following spring after shoots began to grow. The ethephon treatments did not cause observable phytotoxicity to either the flowering pear or liquidambar; there were no visible differences in leaf growth or color between treated and control trees. Also, the ethephon sprays caused no premature blossom drop. This is an especially important result for the flowering pear, which is often planted for its showy bloom.

No visible phytotoxicity on the plants growing beneath or near the treated trees, and therefore contacted by spray drift, was noted at any time. Turfgrass species on the treated sites included Kentucky bluegrass ( $P o a$ pratensis), perennial ryegrass (Lolium perenne) and common Bermudagrass (Cynodon dactylon); woody plants in-

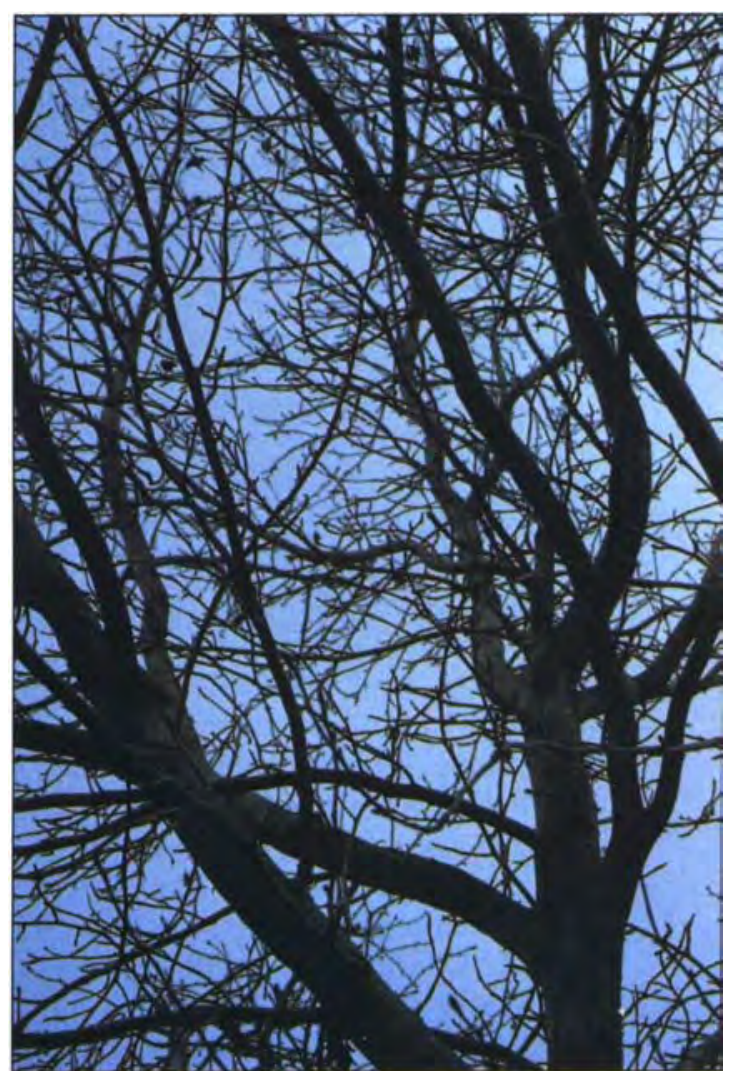

Nearly all of the fruit has been eliminated from this ethephon-treated liquidambar (December 1991).

\begin{tabular}{|c|c|}
\hline \multicolumn{2}{|c|}{$\begin{array}{l}\text { TABLE 1. Effects of ethephon on nuisance fruit } \\
\text { elimination in flowering pear, March } 15,1989\end{array}$} \\
\hline \multirow[t]{2}{*}{ Treatment } & Fruit elimination* \\
\hline & $\%$ \\
\hline Ethephon-1,000 ppm & 95.3 a \\
\hline Ethephon-2,000 ppm & $95.0 \mathrm{a}$ \\
\hline Control & $5.0 \mathrm{~b}$ \\
\hline \multicolumn{2}{|c|}{$\begin{array}{l}\text { Means followed by the same letter within a column } \\
\text { are not significantly different at } 5 \% \text { level (DMRT). }\end{array}$} \\
\hline \multicolumn{2}{|c|}{$\begin{array}{l}\text { TABLE 2. Effects of ethephon on nuisance fruit } \\
\text { elimination in liquidambar, } 1991 \text { and } 1992\end{array}$} \\
\hline \multirow[t]{2}{*}{ Treatment } & Fruit elimination \\
\hline & $\%$ \\
\hline \multicolumn{2}{|l|}{ Trial 1 (April 1, 1991) } \\
\hline Ethephon-1,000 ppm & $99.0 \mathrm{a}$ \\
\hline Ethephon-2,000 ppm & $100.0 \mathrm{a}$ \\
\hline Control & $3.7 \mathrm{~b}$ \\
\hline \multicolumn{2}{|l|}{ Trial 2 (March 18, 1992) } \\
\hline Ethephon-500 ppm & $32.9 \mathrm{a}$ \\
\hline Ethephon-750 ppm & $31.4 \mathrm{a}$ \\
\hline Control & $6.4 \mathrm{~b}$ \\
\hline
\end{tabular}

